\title{
Effect of Maternal Education, Family Income, Mother-Midwife Interface, and the Incidence of Iron Deficiency Anemia in Pemalang, Central Java
}

\author{
Ade Kurniati1), Okid Parama Astirin²), Nunuk Suryani3) \\ 1)Masters Program in Public Health, Universitas Sebelas Maret \\ 2)Faculty of Mathematics and Natural Sciences, Universitas Sebelas Maret \\ 3)Faculty of Teaching and Educational Sciences, Universitas Sebelas Maret
}

\begin{abstract}
Background: Maternal mortality rate was 359 per 100,00o live birth in Indonesia in 2012. An indirect cause of maternal mortality rate is anemia. This study aimed to investigate effect of maternal education, family income, mother-midwife interface, on the incidence of iron deficiency anemia in Pemalang, Central Java.

Subjects and Method: This was an analytical observational with case control design. This study was conducted at Purwoharjo, Rowosari, and Petarukan health centers, Pemalang, Central Java. This study was carried out from March 2 to 27, 2016. A total of 146 pregnant women from the three health centers were selected for this study by fixed disease sampling. This study consisted of pregnant mothers with iron deficiency anemia (cases) and those without iron deficiency anemia (controls) with equal share. The dependent variable was iron deficiency anemia, which was measured by Sahli method. The independent variables were maternal education, family income, and mothermidwife interface. These variables were measured by a set of questionnaire. The data were analyzed by path analysis.

Results: Better knowledge $(b=-1.26 ; p=0.002)$, positive attitude $(b=-1.01 ; p=0.019)$, stronger purchasing power $(\mathrm{b}=-1.16 ; \mathrm{p}=0.004)$ had direct effects on reduced risk of iron deficiency anemia, and they were statistically significant. There were positive effects of higher income on stronger purchasing power $(b=0.63 ; \mathrm{p}=<0.001)$, mother-midwife interface on better knowledge $(b=0.19$; $\mathrm{p}=0.021)$, mother-midwife interface on positive attitude $(\mathrm{b}=0.21 ; \mathrm{p}=0.023)$, and higher education on better knowledge $(\mathrm{b}=0.21 ; \mathrm{p}=0.035)$.

Conclusion: Better knowledge, positive attitude, stronger purchasing power, have direct effects on reduced risk of iron deficiency anemia. Higher income has indirect effect on reduced risk of iron deficiency anemia via stronger purchasing power. Mother-midwife interface has indirect effect on reduced risk of iron deficiency anemia either via better knowledge or positive attitude. It is suggested that pregnant mothers increase their interaction with midwives so that they are able to detect sign and symptom of anemia and to take necessary preventive action.
\end{abstract}

Keywords: iron deficiency anemia, pregnant mother, mother-midwife interface

\section{Correspondence :}

Ade Kurniati. Masters Program in Public Health, Universitas Sebelas Maret. Jl. Ir. Sutami 36A, Surakarta, Central Java.

\section{BACKGROUND}

Maternal Mortality Rate (MMR) is one of indicators which is susceptible towards the quality and accessibility of health care facilities. MMR is also one of the targets which have been specified in the fifth goals of millennium development. It aims to improve maternal health, where the target of 102 / 100,000 live births which will be achieved in 2015 is decreasing the risk of maternal mortality rate. The World Health World Health Organization (WHO) estimates that there are more than 500,000 mothers in the world die every year during pregnancy 
or labor. It means, every minute, there is one woman who dies. The decrease of maternal mortality rate per 100,00o live births is still too slow to reach the Millennium Development Goals/MDGs target in 2015 (Ministry of Health, 2015)

According to the cause, maternal mortality is divided into two: direct and indirect mortality. Direct maternal mortality is an effect of complications of pregnancy, labor, puerperium, and any intervention or improper handling of these complications. Indirect maternal mortality is an effect of existing diseases or diseases that arise during pregnancy which affect pregnancy, such as malaria, anemia, HIV / AIDS, and cardiovascular disease (Wiknjosastro, 2009).

Maternal mortality is one of the important public health problems in Indonesia. The MMR in Indonesia is still high compared to the MMR in other ASEAN countries. The MMR in Indonesia in 2012 was 359 per 100,000 live births. It means that MMR has not reached the target in 2015 by 102/100,00o live births. Based on the data, there are five biggest causes of maternal death: hemorrhage (30.1\%), hypertension in pregnancy (26.9\%), infection (5.5\%), prolonged labor/congestion labor (1.8\%), abortion (1.6\%) and other causes (34.5\%) (Ministry of Health, 2015).

Based on the data above, hemorrhage is a direct cause of maternal mortality. Hemorrhage occurs due to anemia in pregnant women. Besides, anemia during pregnancy is also an indirect cause of maternal mortality. According to Basic Health Research in Indonesia in 2010, the incidence of anemia was still quite high. It was around 50-70 million people, iron deficiency anemia (anemia which occurs when the body does not have enough iron) reached 20\% to $33 \%$ Ministry of Health, 2011).
The incidence rate of anemia towards pregnancy in Central Java in 2007 showed that the prevalence of anemia was $57.7 \%$. It is still higher than the national rate of 50.9\%. In general, it shows that iron deficiency anemia is still become a health problem in Central Java (Central Java Health Office, 2008).

Pemalang Regency in 2014 was the Regency with the highest prevalence of anemia in Central Java. The incidence of anemia towards pregnancy in Pemalang Regency 2014 reached $71.86 \%$. 16,558 out of 27,772 of pregnant women were examined to know the hb level, while those who experienced anemia towards pregnancy were 11,900 pregnant women (Pelamang Regency Health Office 2015).

Based on the study identification of anemia toward pregnant women carried out by Ridayanti (2012), it showed that there was a correlation between maternal education level and the incidence of anemia in their pregnancy at Banguntapan I community health center, Bantul. The higher maternal knowledge about anemia showed the more positive the maternal attitude in preventing anemia. A study conducted by Setyaningsih (2008) stated that there was a correlation between interaction, knowledge and attitude towards maternal practices in preventing deficiency anemia. Abdelhafez (2012) also stated that low education level is associated with an increased risk of anemia $(\mathrm{p}=18,821)$. A study conducted by Suwandi (2003) showed that education level and family income had a significant correlation with the incidence of anemia toward pregnant women.

This study aimed to investigate effect of maternal education, family income, mother-midwife interface, on the incidence of iron deficiency anemia in Pemalang Regency. 


\section{SUBJECTS AND METHOD \\ 1. Study Design \\ This study used an analytical observational with case control design. This study was conducted at Purwoharjo, Rowosari, and Petarukan community health centers, Pe- malang, Central Java. This study was car- ried out from March 2 to 27, 2016.}

\section{Population and Sampling}

The study population consisted of pregnant mothers at Purwoharjo, Rowosari, and Petarukan community health centers, Pemalang. A total of 146 pregnant women were selected for this study by fixed disease sampling.

\section{Study Variables}

The dependent variable was iron deficiency anemia. The independent variables were maternal education, family income, and mothermidwife interface.

\section{Study Instruments}

The iron deficiency anemia was measured by Sahli method. The other data were collected by a set of questionnaire.

\section{Data Analysis}

The data were analyzed by path analysis.

\section{RESULTS \\ 1. Sample characteristics}

The characteristics of study subjects based on gestational age: 11 people in the first trimester (11\%), 85 people in the second trimester (58.2\%), 45 people in the third semester (30.8\%). There were 116 who had low education (79\%) and 30 people who had higher education (21\%).

There were 93 people who had high family income (63.9\%) and 36.3 people who had low family income (36.3\%). There were 82 people who had low purchasing power ability (56.2\%). There were 88 people who had good mother-midwife interface (60\%) and 58 people who had low mothermidwife interface (40\%). There were 77 people who had good maternal education (52.7\%) and 69 people who had lack maternal education (47.3\%). There were 49 poeple who had positive maternal attitude (33.6\%) and 97 people who had negative maternal attitude (66.4\%).

\section{Path Analysis}

\section{a. Model Specification}

The initial model in path analysis can be seen in Figure 1.

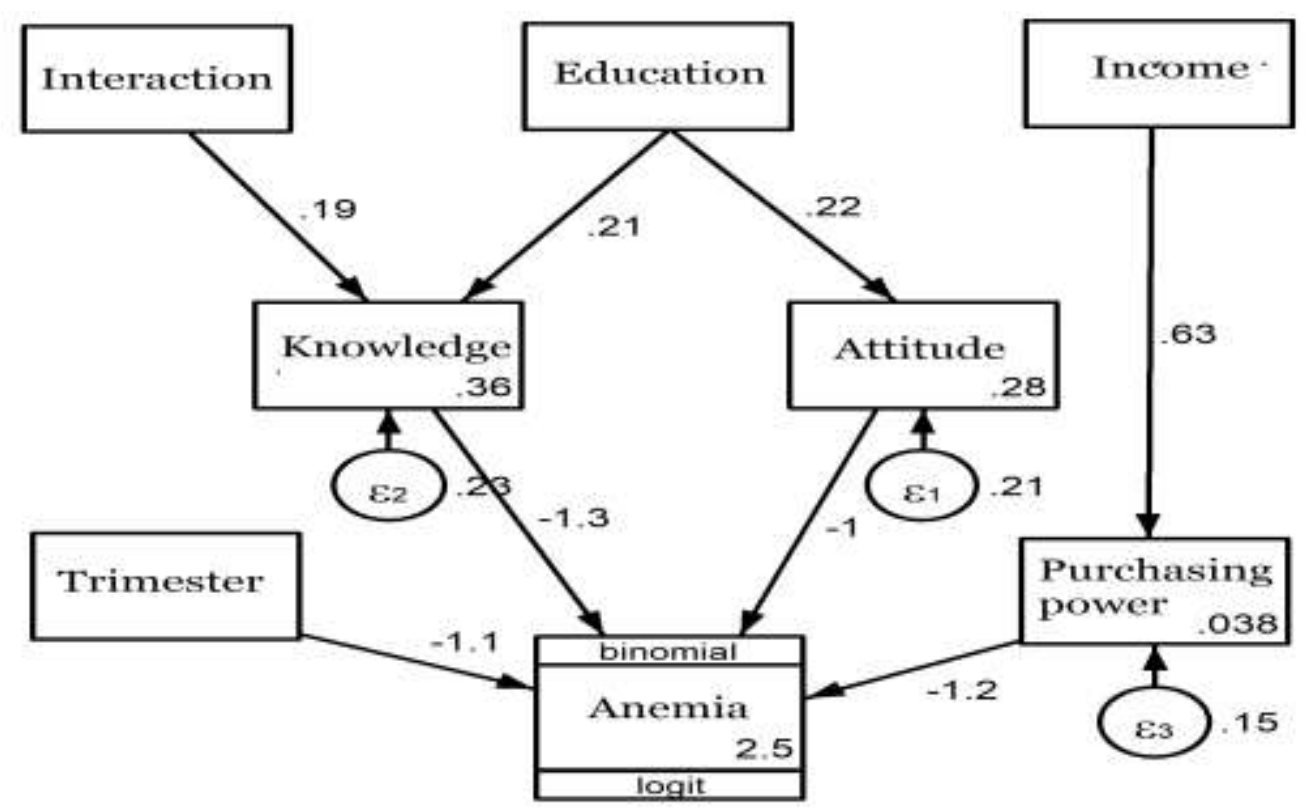

Figure 1. Path Model 


\section{b. Fit Model and Parameter Es- timation}

The suitability of the path analysis model made by authors based on the theory was checked with the best variable correlation model based on computer (SPSS). It was called saturation model based on sample data which was collected by authors. Figure
2 showed the structural model after doing estimation. The parameter estimation showed the cause-effect correlation of the variable which is indicated by the regression coefficient (b). The regression coefficient showed the correlation of the dependent and independent variables in the original measurement unit.

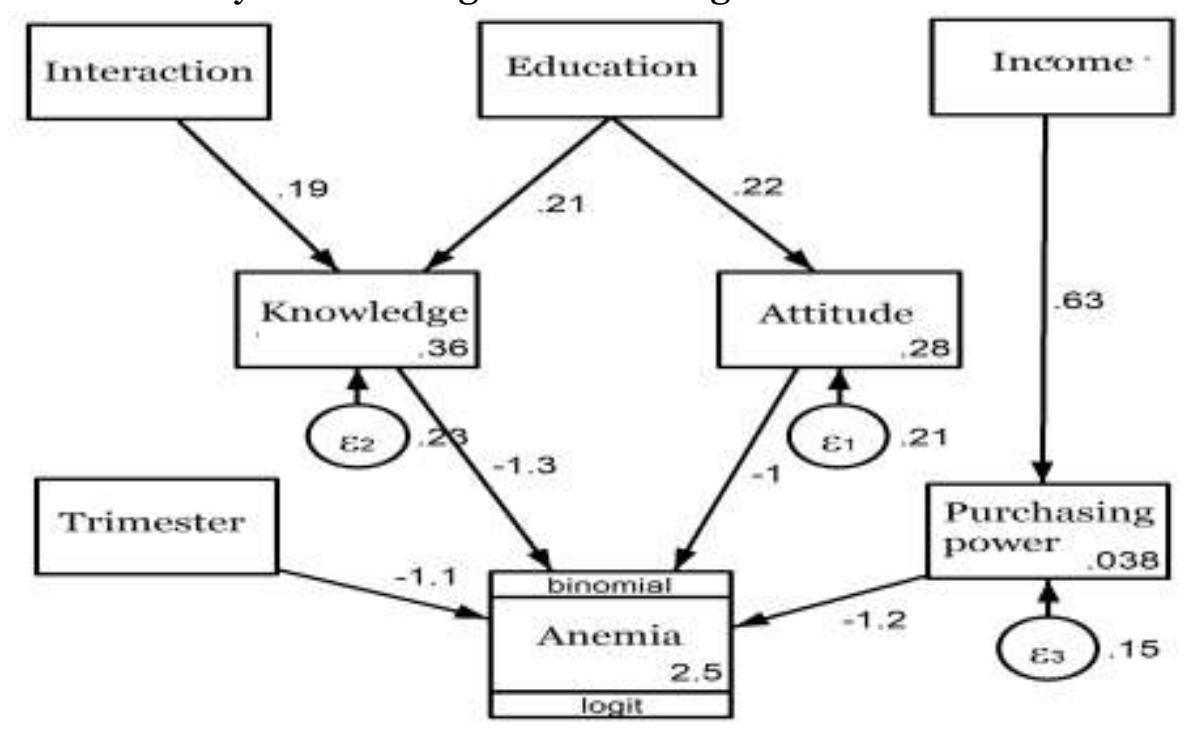

Figure 2. Path Model with Estimation.

Table 1. The result of path analysis on the effects of maternal education, family income, and mother-midwife interface on the incidence of deficiency anemia in Pemalang Regency

\begin{tabular}{|c|c|c|c|c|c|c|}
\hline \multirow[b]{2}{*}{$\begin{array}{c}\text { Dependent } \\
\text { Variables }\end{array}$} & & \multirow[b]{2}{*}{$\begin{array}{l}\text { Independent } \\
\text { Variables }\end{array}$} & \multirow[b]{2}{*}{ b } & \multicolumn{2}{|c|}{$95 \%$ CI } & \multirow[b]{2}{*}{$\mathbf{p}$} \\
\hline & & & & $\begin{array}{l}\text { Lower } \\
\text { limit }\end{array}$ & $\begin{array}{l}\text { Upper } \\
\text { limit }\end{array}$ & \\
\hline \multicolumn{7}{|l|}{ Indirect Effect } \\
\hline \multirow[t]{2}{*}{ Knowledge } & $\leftarrow$ & Interaction & 0.19 & 0.03 & 0.35 & 0.021 \\
\hline & $\leftarrow$ & Education & 0.21 & 0.02 & 0.40 & 0.035 \\
\hline Attitude & $\leftarrow$ & Education & 0.21 & 0.03 & 0.40 & 0.023 \\
\hline $\begin{array}{l}\text { Purchasing Power } \\
\text { Direct Effect }\end{array}$ & $\leftarrow$ & Income & 0.63 & 0.49 & 0.76 & $<0.001$ \\
\hline \multirow[t]{4}{*}{ Anemia } & $\leftarrow$ & Attitude & -1.01 & -1.89 & -0.16 & 0.019 \\
\hline & $\leftarrow$ & Knowledge & -1.26 & -2.05 & -0.47 & 0.002 \\
\hline & $\leftarrow$ & Purchasing Power & -1.16 & -1.94 & -0.37 & 0.004 \\
\hline & $\leftarrow$ & Trimester & -1.06 & -1.86 & -0.26 & 0.009 \\
\hline Likelihood Ratio p & -3 & & & & & \\
\hline
\end{tabular}

Table 1 showed the result of calculation using computer software program of SPSS 22 for windows. It was found that a regression coefficient $\mathrm{b}$ between family income and purchasing power was positive by 0.63 with $\mathrm{p}<0.001$ which was significant. Regression 
coefficient $\mathrm{b}$ between interaction and knowledge was 0.19 with $\mathrm{p}=0.021$ which was significant. The regression coefficient $\mathrm{b}$ between education and knowledge was positive by 0.21 with $p=0.035$ which was significant. The regression coefficient $\mathrm{b}$ between education and attitudes was positive by 0.21 with $\mathrm{p}=0.023$ which was significant. The regression coefficient $b$ between attitude and anemia was negative by -1.01 with $\mathrm{p}=0.019$ which was significant. The regression coefficient $\mathrm{b}$ between trimester and anemia was negative by $-\mathbf{1 . 0 6}$ with $\mathrm{p}=$ 0.009 which was significant. The regression coefficient $b$ between knowledge and anemia was negative by -1.26 with $\mathrm{p}=0.002$ which was significant. The regression coefficient $b$ between purchasing power and anemia was negative by -1.16 with $\mathrm{p}=0.004$ which was significant.

c. Model Respecification

The model in this study was in accordance with the sample data which was indicated by the saturation model and the regression coefficient that were more than zero which statistically significant. Therefore, path analysis model did not need to be re-created because the model that was matches with the sample data had been obtained.

\section{DISCUSSION}

\section{The effect of education on anemia}

The analysis result showed that there was an indirect effect between education and anemia in Pemalang Regency through education and attitude. From the effect between education and knowledge, it was found that regression coefficient $b$ was 0.21 with $\mathrm{p}=0.035$ which was significant; from the effect through knowledge and anemia, it was found that regression coefficient $b$ was -1.26 with $\mathrm{p}=0.002$ which was significant; then, from the effect through education and attitude, it was found that regression coeffi- cient $b$ was 0.21 with $p=0.023$ which was significant; from the effect through attitude and anemia, it was found that regression coefficient $\mathrm{b}$ was -1.01 with $\mathrm{p}=0.019$ which was significant.

The parents' educational background, especially mother, is one of the important elements which help to determine the type and amount of food consumed by the family. Mothers who have higher education will choose food for family consumption which is not only based on family tastes but also based on fulfilment of nutritional needs and family abilities (Proverawati, 2009).

Meanwhile, according to Hariyani (2011), education, in this case is usually related to knowledge. It affects the food selection and the fulfilment of nutritional needs. For example, someone's principal with low education is usually prioritized a pleasure. Otherwise, people who has higher education have a tendency of selecting nutritional food. Lower education will effects education and the way people think, such as knowledge and the way people think about the importance of health (Manuaba, 2001).

Maternal education is important for doing daily activities at home and social environment, so it can run well as expected. Based on a study conducted by Ridayanti, low education caused the ability of receiving health information and awareness of health decreased. This condition caused pregnant women were unable to fulfill the nutritional needs during pregnancy. It caused anemia during pregnancy. Based on the that result, it can be concluded that this study is in line with the theory and the study conducted by Ridayanti that there was a positive indirect effect between education and anemia, through knowledge and attitude which affects anemia.

\section{The effect of family income on anemia}


The result of the analysis showed that there was a positive indirect effect between family income and anemia in Pemalang Regency. Based on result of the effect of family income towards purchasing power,it was found that the regression coefficient $\mathrm{b}$ was 0.63 with $\mathrm{p}<0.001$. The regression coefficient $\mathrm{b}$ was -1.16 with $p=0.004$ through purchasing power and anemia.

Economy is always become a factor which determines a healthy pregnancy process. Pregnant woman can get pregnancy check up regularly, plan her labor to health workers, and make other preparations well due to good family economic condition. However, having good planning and making maternity savings from the begining will make pregancy process run well (Eddy, 2007).

Socio-economic factor of a family is related to family income. Income affects the purchasing power and daily food consumption. Nutrient intake is largely determined by the family purchasing power. Socio-economic status is useful to make sure whether mother has the ability to buy and choose nutrient-rich food. Meanwhile, the utilization of health facilities by the community and low socio-economics is still low and the service itself is far from normal rate (Almatsier, 2003). Pregnant woman who is in malnutrition condition, especially iron deficiency, generally causes pale face, lethargy, fatigue, dizziness, lost of appetite, and weak immune system (Sedia-oetama, 2008).

A study conducted by Ghosh in India found that pregnant women who had low socio-economic had a higher chance of getting anemia. It was also expressed by Bhargava who conducted a study in Bangladesh. It showedthat pregnant women with high economic level had a lower risk of anemia compared to those with a low economy.

Based on that result, it can be concluded that this study is in line with the theory and study conducted by Ghosh and Bhargava which stated that there was an effect between family income and anemia. The effect was negative, through purchasing power ability which affected anemia.

\section{The effect of mother-midwife inter- face towards anemia}

The result of the analysis showed that there was an indirect effect between mother-midwife interface and anemia in pregnant mother in Pemalang Regency. First, the regression coefficient $b$ was 0.19 with $\mathrm{p}=0.021$ through interaction of midwife and knowledge. Second, the regression coefficient $b$ was -1.26 with $\mathrm{p}=0.002$ through knowledge and anemia.

Midwife is expected to carry out the good role in the interaction between midwife and pregnant woman. The role of midwife which is related to anemia in pregnancy can be done by prevention stage. Prevention levels consist of 3 parts, namely primary, secondary and tertiary prevention. In this primary prevention, midwife can be an educator such as providing nutrition education in the form of rich-Fe food intake and consumption of iron supplements or supplement for blood enhancement for 90 days. Midwife can become a facilitator with people who supply supplement for blood enhancement for pregnant women. Midwife can also be a motivator for pregnant woman to get pregnancy check up regularly at the nearest health care service and motivate the family of pregnant woman to always support things which is done for pregnant woman to prevent acute anemia.

Secondary prevention as care giver is doing screening (aerly detection) such as doing $\mathrm{Hb}$ check up. In addition, midwife can also become an inventor of a case and author (Junaidi, 2007).

The roles of midwives in interacting with clients are giving education and counseling, especially for pregnant women about 
overcoming health problems, specifically anemia in pregnancy; It can reduce the incidence of anemia in pregnant women (Soepardan, 2007).

The roles of health workers, especially midwives are providing counseling about pregnancy and providing nutritional assistance for pregnant women, so anemia in pregnancy does not occur; It is a special attraction in increasing pregnant women visit (Yuwi, 2006).

\section{The effect of knowledge towards anemia}

The analysis result showed that there was a direct effect between knowledge and anemia in pregnant women, Pemalang Regency. From the effect, it was found that the regression coefficient $\mathrm{b}$ was -1.26 with $\mathrm{p}=$ 0.002 which was significant. Therefore, it can be concluded that there was a direct correlation between knowledge with anemia which is negative.

According to Purbadewi (2013), pregnant woman who is lack of knowledge about anemia will behave negatively, while pregnant woman who has good knowledge will behave positively to prevent or treat anemia. Therefore, the knowledge about anemia to pregnant women needs to be increased. Counseling, based on its characteristics can be held; therefore, counseling materials can be understood by all pregnant women even though the characteristics are different. For example, counseling to loweducated pregnant women uses different methods coompared to high-educated pregnant women.

A study conducted by Purbadewi showed that pregnant women who have low and sufficient level of knowledge indicates the low understanding of anemia, causes of anemia, signs and symptoms of anemia, consequences and anemia prevention. As a result, the health behavior of pregnant women to prevent anemia in pregnancy is not optimal. The pregnant women who lack knowledge about anemia cause the decrease of iron-food consumption during pregnancy; it occurs due to factor of ignorance.

\section{The effect of attitude towards ane- mia}

The analysis result showed that there was a negative effect between attitude and anemia towards pregnant women in Pemalang Regency. A positive attitude towards preventing iron deficiency anemia will affect a person to prevent and overcome anemia. According to Azwar (2010), the factor which affect the formation of human attitude is personal experience; It is formation of impression or response to object which is a complex process in the individual; It involves the individual itself. To be the basis in forming attitudes, a very good impression of the personal experience is needed.

Therefore, formation attitude will be easier to be formed if the personal experience involves emotion, deeper and longer understanding and the influence of other people who are considered as important things such as parents, people who have higher social status, peers, and etc. In the context of cultural influences, only strong and stable individual personality can eliminate the dominance of culture that forms an individual attitude. One of the methods is using mass media as a means of communication. Various forms of mass media such as television, radio, newspapers, magazines, and others, have a big influence in forming people's opinions and beliefs.

\section{The effect of purchasing power to- wards anemia}

The analysis result showed that there was a positive effect between purchasing power and anemia in pregnant mother in Pemalang Regency. Based on the significance of the association it was found that the regression coefficient $\mathrm{b}$ was -1.16 with $\mathrm{p}=0.014$. 
There was a correlation between socio-economic factors and family income. Income affected purchasing power and daily food consumption. The nutrient intake is largely determined by purchasing power of the family. Socio-economic status is useful to make sure whether the mother has the ability to buy and choose nutrient-rich food. Meanwhile, the utilization of health facilities by the community and low socioeconomics is still low and the service itself is far from normal rate (Almatsier, 2003). However, there was another thing found in this study; the high purchasing power did not guarantee the fulfilment of good nutrient intake. This is related to pregnant women who do not understand how to choose nutrient-rich food and to process food, so that the iron does not decrease too much. If the daily food consumption is similar, the imbalance on the input of nutrients which are needed will occur. Consuming a variety of food will decrease the deficient nutrients on other food; so, the nutrients become balanced and it affects the anemia in pregnancy. Therefore, the fulfilment of balanced nutrition is not only fulfilled by one type of food, but it must consist of various food ingredients, especially iron element is needed to be considered.

\section{The correlation between trimester and anemia}

The analysis result showed that there was a negative effect between trimester and anemia in pregnant women in Pemalang District. Based on the significance of the association it was found that the regression coefficient $b$ was -1.06 was $p=0.009$.

Anemia is often found in the pregnancy period. It is because the need of food substance increases during pregnancy. The changes in blood and bone marrow occur. In pregnancy, the increase of blood (hypervolemia) can occur, but blood cells are less compared to the increase of plasma; there- fore, it causes blood dilution (Wikjosastro, 2010).

Anemia in pregnancy is a condition of pregnant women where the hemoglobin level is below $11 \mathrm{~g} \%$ in the first dan third trimester or $<10.5 \mathrm{~g} \%$ in the second trimester (Wiknjo-sastro, 2009). During the second trimester, the need for blood-forming substances, especially iron, rises sharply to double compared to the condition when mother is not pregnant. This condition is caused by the increase of maternal blood volume due to the fetus need of oxygen and nutrients carried by red blood cells (Soebroto, 2009).

Based on the analysis result, it can be concluded that there is a direct effect between trimester and anemia. Anemia in pregnancy is directly related to knowledge, attitude, purchasing power, and trimester. Meanwhile, the indirect effect are education, family income and interaction.

\section{REFERENCE}

Abdelhafez (2012). Prevalence and risk factors of anemia among a sample of pregnant females attending primary health care centers in Makkah, Saudi Arabia. Pakistan Journal of Nutrition, 11(12): 1113-1120.

Almatsier S (2003). Prinsip Dasar Ilmu Gizi. Jakarta: Gramedia Pustaka Utama.

Central Java Health Office (2008). Profil Kesehatan Provinsi Jawa Tengah.

Ghosh S (2009). Exploring socioeconomic vulnerability of anaemia among women in Eastern Indian States. Jurnal Biososial Science, 41: 763-787.

Ikhsan (2009). Anemia dalam kehamilan. Jakarta: Medika Pustaka.

Manuaba IBG (2001). Kapita selekta penatalaksanaan rutin obstetri ginekologi dan KB. Jakarta : EGC. 
Ministry of Health (2012). AKI di Indonesia. Accesed 5 November 2015

Ministry of Health (2015). Profil Kesehatan Indonesia 2014.

Ministry of Health(2012). Profil Kesehatan Indonesia. Jakarta.

Pemalang Regency Health Office. (2014). Profil Kesehatan Pemalang.

Proverawati (2009). Buku ajar Gizi Untuk Kebidanan.Yogyakarta: Maha Medika.

Purbadewi L (2013). Hubungan tingkat pengetahuan tentang anemia dengan kejadian anemia pada ibu hamil. Se- marang: Universitas Muhammadiyah Semarang.

Soebroto I (2009). Cara Mudah Mengatasi Anemia. Yogyakarta: Bangkit.

Soepardan (2007). Konsep Kebidanan. Jakarta: EGC.

Wiknjosastro (2009). Ilmu Kebidanan. Jakarta: Yayasan Bina Pustaka Sarwono. 